\title{
Elidegenedés a szabadságtól
}

$\mathbf{N}$

$\mathbf{F}$

0

$\mathbf{R}$

$\mathbf{M}$

Á

C

I

ó

S

$\mathrm{T}$

Á

$\mathbf{R}$

S

A

D

Így hivatkozzon erre a cikkre:

Tófalvy Tamás. „Elidegenedés a szabadságtól”.

Információs Társadalom II, 4. szám (2002): 154-155.

= https://dx.doi.org/10.22503/inftars.II.2002.4.10

A folyóiratban közölt müvek

a Creative Commons Nevezd meg! - Ne add el! - Így add tovább! 4.0

Nemzetközi Licenc feltételeinek megfelelően használhatók. 
Tó f a lvy Ta má s

\title{
Elidegenedés a szabadságtól
}

\author{
„Minden egyoldalúság a kiegészités felfedezésének egy lehetösége” \\ Steve Talbott
}

Minden kultúrakritikának sajátja, hogy a fennálló rendszert illető vádjait egy másik korhoz, a kultúra egy másik állapotához, vagy egy esetleg még nem létező utópikus példához viszonyítva fogalmazza meg. Sokszor még az is előfordulhat, hogy átvéve a „vezetô paradigma” szerepét, a radikálisan más hozzáállás alakítja magának a jelennek a formálódását. És még hosszan lehetne folytatni a sort, hogy hol, mikor milyen párhuzamokat vagy éppen ellentéteket kívánt meg az aktuális jelen - helytálló vagy hibás, esetleg szükségtelen - kritikája.

A gond ott adódik, hogy lehetetlennek tűnik meghúzni a határt, hogy mikor kezdődött (és mikor fog véget érni?) az a nem utolsósorban mindennapi felfogás, amely kizárólagosan egy ilyen viszonyban látja az egyes kulturális jelenségek értékét vagy éppen negativitását; és ott, hogy a kritikus döntés szemszögéből lehet-e egyáltalán hibás döntésről és hibás diagnózisról beszélni.

És bármennyire az az értelmezés alapállása, hogy a kultúrakutató fölül tud emelkedni ezen a felfogáson, Talbottnak ez úgy tűnik, mégsem sikerül: nem hagyja el azt a pozíciót, ami a mai modern nyugati (Ingold szerint földrajzilag körülhatárolhatatlan) ember sajátja, holott tanulmányának nem elhanyagolható problémája az, hogy hogyan formálja egésszé, értelmezhetôvé egy kor (vagy ha úgy tetszik episztémé) embere a saját világképét. Mintha nem tudna, így mi sem tudunk megszabadulni attól az érzéstôl, hogy ami túl van a hagyományunk határain, az átlép a primitív szférájába, ami pedig távolabb esik a személyes utópiánk kertjeitôl, az már embertelen, hideg, és ily módon szintén nem kívánatos.

Pedig az absztrakció és elidegenítés fogalma is csak történetileg, visszatekintve létezik, de a változás egyes szakaszaiban nem tapasztalható. Az átmenet folyamatos, a mindenkori visszatekintô pozíció mégis lehorgonyzott, értékelő. Ez a fenomenológiai vonatkozás mindenképpen megért volna legalább egy utalást, hogy relativizálja, vagy legalábbis árnyalja az egyes konklúziókat.

Egy konkrét esetben is erôsen vitathatónak érzem Talbottnak a tér és idő absztrakciójának párhuzamaira vonatkozó megállapításait. Az idő egységekre osztása és órával való mérése, mint fokozott absztrakció az organikus idôélménnyel szemben, érthetô és mindennapi tapasztalat, de ezzel a tér háromdimenziós ábrázolását a múvészetben nem hiszem, hogy analóg folyamatként lehetne szemlélni. Hiszen az óra ideje nem „valós” struktúra, ellenben a tér három dimenziója a mi élményvilágunkban valós, és ezért a térbeli ábrázolások fejlődése nem annyira fokozott absztrakciót, mint inkább reflexiót, ha úgy tetszik természetesebb vizualitást jelentenek, még akkor is, 
ha Talbott szerint mindez egy fordított, absztrakt(abb) folyamatban valósult meg, a tárgyak térbe illesztésével, és nem a tárgyak terének megalkotásával.

Ez, akárcsak a modern individuum - Talbott szerint (is) - információszelektáláson alapuló léte, (amely állítás megint igencsak vitatható) inkább mennyiségi, mint minőségi változást jelent az információs társadalom előtti korokhoz képest, különösen, hogy ez az individuum is inkább a hagyománnyal szembeállítva, mintsem a jelenben létezik. Ezt az állásfoglalást, ahogy az eddigieket is, ismét csak a visszatekintő szempont, vagy még inkább a tézis prekoncepciója generálja, de nem biztos, hogy ez a legjobb út a technológia-ember kapcsolat értékrendszerének a megértéséhez.

Tófaloy Tamás egyetemi hallgató (PTE BTK) 